\title{
C.R. XIlle Colloque Européen d'Arachnologie, Neuchâtel 2-6 septembre 1991
}

Bulletin de la Société neuchâteloise des Sciences naturelles, Tome 116, Fascicule 1, 300 pp., ISSN 0366-3469.

$\mathrm{Zu}$ beziehen über Pierre-Alain Fürst, Ecoconseil, R. D.-Jeanrichard 44, $\mathrm{CH}-2300$ La Chaux-de-Fonds. Preis: 50 Schweizer Franken.

Das 13. Europäische Arachnologische Kolloquium liegt nunmehr schon zwei Jahre zurück. Es fand vom 2.-6. September 1991 in Neuchâtel (Schweiz) statt, gemeinsam organisiert von der Europäischen Arachnologischen Gesellschaft, dem Zoologischen Institut der Universität Neuchâtel und der Arachnologen-Gruppe Neuchâtel. Etwa 100 Wissenschaftler/-innen aus 15 Staaten nahmen daran teil.

Die in Neuchâtel vorgetragenen wissenschaftlichen Ergebnisse liegen nun gedruckt als Tagungsbericht vor. Enthalten sind v.a. Beiträge aus den Fachgebieten Faunistik/Zoogeographie, Ökologie, Bioindikation, Physiologie sowie Fortpflanzungs- und Populationsbiologie. Im einzelnen sind dies folgende Arbeiten:

ACOSTA, L. E.: Escorpiones y opiliones de la provincia de Córdoba (Argentina): diversidad y zoogeogratía

ALDERWEIRELDT, M. \& R. JOCQUÉ: New data on Donacosa merlini (Araneae, Lycosidae), a threatened species?

BLICK, T. \& P. BLISS: Spinnentiere und Laufkäfer am Waldrand (Arachnida: Araneae, Opiliones, Pseudoscorpiones; Insecta: Coleoptera: Carabidae).

BLISS, P.: Neue Funde von Astrobunus laevipes (Arachnida, Opiliones, Phalangiidae)

BOEVÉ, J.-L.: The injection of venom by a spider (Cupiennius salei, Ctenidae) and the weight of an insect prey (Acheta domesticus, Gryllidae)

BUCHAR, J.: The use of faunistical data for biomonitoring

CANARD, A.: Résistance à la sécheresse, revêtement tégum entaire et valence écologique de Salticidés

CODDINGTON, J. A. \& P.-A. FÜRST: Proposed style for computer files of arachnological references

CONDÉ, B.: Le dimorphisme sexuel des Palpigrades

FÜRST, P.-A. \& G. BLANDENIER: Psilochorus simoni(BERLAND, 1911) (Araneae, Pholcidae): Découvertes de nouvelles stations suisses et discussions de son écologie

HAJER, J.: Notes on the spinning apparatus of the spiders Hyptiotes paradoxus C. L. K., 1834, and Uloborus walckenaerius LATR., 1806 (Araneae: Uloboridae) 
HÄNGGI, A.: Minimale Flächengröße zur Erhaltung standorttypischer Spinnengemeinschaften

- Ergebnisse eines Vorversuches

HAUPT, J.: Lebensdauer von mesothelen Spinnen

van HELSDINGEN, P.J.: Can Macrothele calpeiana (WALCKENAER) (Araneae, Hexathelidae)

be used as a bio-indicator?

JUDSON, M. L. I.: The gonosacs ('gonopods') of female pseudoscorpions (Arachnida, Chelonethi)

KAJAK, A.: Long-term changes in spider communities of drained fens

KOOMEN, P.: Experiences with spider exhibitions in The Netherlands

KOPONEN, S.: On the biogeography and faunistics of European spiders: latitude, altitude and insularity

KUHN-NENTWIG, L. \& W. NENTWIG: Zur Biochemie des Giftes von Cupiennius salei (Ctenidae)

LUCZAK, J.: Ecotone zones between forest islands and crop fields in the Masurian Lakeland, Poland, as barriers for migration of spiders to crop fields

MALLI, H. \& W. NENTWIG: Ontogenetische Aspekte der Giftdrüsen und des Giftes von Cupiennius salei (Araneae: Ctenidae)

MARC, P.: Interspecific and intraspecific interactions between spider species from apple orchards

MÜLHAUSER, B. \& J. CURTY: Comparaison de 2 méthodes d'étude surl'écologie et la structure des peuplements d'araignées des lisières

PRÓSZYNSKI, J.: Zoogeographical features of the European Fauna of Salticidae (Araneae), an overview of 30 years of research

RAMOUSSE, R.: Allométrie de la reproduction chez les femelles d'Araneus (Larinioides) suspicax O. PICKARD-CAMBRIDGE 1876, élevées en laboratoire

RUZICKA, V.: Structure and ecology of invertebrates communities of stony debris in Czech Republic. Research projekt

SCHMIDT, G.: Further crossing experiments in Latrodectus species (Araneida: Theridiidae)

SIMON, U.: Temporal species serie of web-spiders (Arachnida: Araneae) as a result of pine tree bark-structure

STUDER, A. \&W. NENTWIG: Zur Beutetierspezifität des Giftes von Cupiennius salei (Araneae: Ctenidae)

TARABAEV, C.: Karakurt (spider genus Latrodectus) in Kazachstan: distribution and problem of victim registration

TONGIORGI, P. \& C. SOLA: Pardosa nigristernis DENIS, 1966. A North African component of the Italian and Spanish arachnofauna

UHL, G.: Sperm storage and repeated egg production in female Pholcus phalangioides FUESSLIN (Araneae)

VILLEPOUX, O.: Remarques sur la répartition des araignées dans un marais de plaine

YSNEL, F.: Data points for a study of population dynamics of an orb-weaving spider (Larinioides cornutus, Araneae, Araneidae)

ZYUZIN, A. A., C. TARABAEV \& A. A. FYODOROV: The spider fauna of the Karatau montain range 
Nur als Zusammenfassung publiziert wurden folgende Arbeiten:

DECAE, A. E.: The trapdoor-burrow: the success of a defense system LANG, A.: Silk of the nuptial gift of the spider Pisaura mirabilis

MAURER, R.: Zur Gattung Cybaeus im Alpenraum (Araneae: Agelenidae, Cybaeinae) ZWÖRNER-WEICKMANN, D. \& S. MOOSMANN: Neue Erfahrungen mit Giftspinnen ZWÖRNER-WEICKMANN, D., S. MOOSMANN \& M. FORMELLA: Springspinnen: Interessatte Beobachtungen bei der Haltung und Zucht von Salticiden

Der Redaktion ist eine ansprechende Gestaltung sowohl des Bandes als auch der einzelnen Beiträge gelungen. Pierre-Alain FÜRST und Gilles MULHAUSER gebührt Dank für diese Leistung! Leider wird der Gesamteindruck durch einige Druckfehler etwas geschmälert. Sie sind offensichtlich in den meisten Fällen auf Probleme der computergestützten Textbearbeitung zurückzuführen.

Peter BLISS

\section{Aufruf zur Mitarbeit}

Wer einige von mir neu erstellte Bestimmungs-Tabellen mitteleuropäischer Spinnen (Gattungen, Arten) vor ihrer Publikation auf Brauchbarkeit/Fehler überprüfen möchte, melde sich bitte bei:

Jörg WUNDERLICH, Hindenburgstr. 94, D-75334 Straubenhardt Tel. 07082/3411.

\section{Aufruf zur Mitarbeit}

Gesucht werden Tiere der Art Pardosa (Wadicosa) venatrix. Wer kann mir bitte ein Paar dieser im Mittelmeergebiet vorkommenden Wolfspinnenart überlassen oder leihweise zusenden?

Dr. Hozumi TANAKA, Sonoda Gakuen Womens's College, 29-1, 7 chome Minamitsukaguchi-cho, Amagasaki-shi, Hyogo 661, JAPAN 